\title{
The Salt Industry In Mexico
}

Carlos Miguel Barber Kuri, (E-mail: cbarber@ds.uas.mx), Universidad Anáhuac México Sur

\begin{abstract}
Salt is one of the products that Mexico can market on a large scale because it is one of its most abundant natural resources, and very much in demand. Mexican salt mines are recognized all over the world and are an important part of Mexican history. ${ }^{1}$
\end{abstract}

\section{HISTORY OF SALT IN MEXICO}

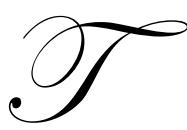

he salt mining industry in Mexico experienced great changes in the last decade of the $19^{\text {th }}$ century as people began consuming more and more salt.

History points out a series of sudden changes in the use of this product. For example, during the Mexican Revolution, which to a certain extent caused a drastic decrease in the demand for salt, it was necessary for the State to intervene in order to regulate and decrease the production of salt to avoid overproduction.

After political and economic unrest caused by this revolution, Mexico began building a multitude of chemical plants, turning this industry into one of the main salt producing centers.

As well, ever since the 50s, the idea to export salt to Japan was examined as Japan has a shortage of the product. Many plans were prepared with this in mind but were not carried out at the time because there was no real infrastructure for its transportation or for its production, which meant they could not guarantee meeting the demand. So it was decided that Mexico would begin building one of the largest solar salt plants in the world, with funds from foreign investment, in Guerrero Negro, Baja California Sur. This plant was later nationalized, making it possible for Mexico to become one of the main exporters of salt, competing with Australia and Chile for the Japanese market. Together with a promising national market, the salt industry is definitely a very interesting business to pursue.

\section{SOME INFORMATION ON GUERRERO NEGRO}

The name Guerrero Negro, as it is known internationally, comes from the legend of the ship Black Warrior that sank along its coasts, with a cargo full of gold and diamonds.

Guerrero Negro is located on the Peninsula of Baja California Sur in the State of Baja California Sur.

Mexico saw the birth of this area in 1957, the same year when Daniel Ludwig, a North American visionary who came up with the idea to build the Acapulco Princess Hotel, took the initiative to install a plant that would supply the west coast of the USA with salt.

Guerrero Negro is known for its huge salt mines, considered to be the largest in the world and which give origin and life to this place.

\footnotetext{
${ }^{1}$ Several different documents were used to draw up this case and are cited throughout this paper. The following is a synthesis of this information and is presented for academic purposes.

The collaboration of MBA Rogelio EpigmenioCastillo Aguilera, Professor Gabriela Bleck Padierna and Karla Rosa Dávila Hernández in revising and preparing this document is greatly appreciated
} 


\section{NATIONAL PRODUCTION}

Due to its geographic peculiarities, Mexico has focused its production on sea salt, obtainable from the shores of the Gulf of Mexico, the Pacific Ocean and from the del Rey solar lakes in Coahuila, Laguna del Jaco in Chihuahua, and Laguna de Santa María in San Luis Potosí. Salt is also produced in Mexico from underground brine found in Veracruz and Nuevo León.

However, the largest production of salt in Mexico comes from Baja California Sur, specifically from Guerrero Negro, the rest of the production comes from 14 states in the Mexican Republic; Veracruz, Yucatán, Sonora, and Nuevo León are among the most important.

Guerrero Negro generates $80 \%$ of the production in the nation, which is almost entirely for exportation. The salt mines in Guerrero Negro being mined cover an area of 22,000 hectares while 3,000 hectares are used for the crystallization of salt.

The other $20 \%$ is for domestic consumption and $90 \%$ of this production is concentrated in Veracruz (where the leading company is located), followed by Yucatán, Nuevo León and Coahuila. "In 2002, Mexico produced 7.8 million tons of salt.".

Table 1. National Salt Producers

\begin{tabular}{|c|c|}
\hline Name & Production Capacity Yearly \\
\hline Exportadora De Sal, Guerrero Negro & $7,000,000$ tons \\
\hline Sales Del Itsmo & 510,000 tons \\
\hline Pennwalt & 478,000 tons \\
\hline Industrial Salinera De Yucatán & 220,000 tons \\
\hline Salinas De Lobos & 75,000 tons \\
\hline Cáa. Salinera Del Itsmo & 18,000 tons \\
\hline Salineros De Colima & 14,000 tons \\
\hline Salineros Del Golfo & 14,000 tons \\
\hline
\end{tabular}

${ }^{2}$ Rf. http://www.amisac.org.mx/page14.html (8 "Producción Nacional de Sal". (February 8, 2005) 
Table 2. Salt Exports From 1993 To $2003^{3}$

\begin{tabular}{|c|c|c|c|}
\hline Year & Dollars & Tons \\
\hline 1993 & $76,552,117$ & $6,038,996$ \\
\hline 1994 & $85,286,887$ & $7,130,497$ \\
\hline 1995 & $88,281,736$ & $7,179,276$ \\
\hline 1996 & $89,987,079$ & $7,609,824$ \\
\hline 1997 & $85,090,833$ & $7,101,022$ \\
\hline 1998 & $76,633,713$ & $6,277,188$ \\
\hline 1999 & $78,989,582$ & $6,864,527$ \\
\hline 2000 & $87,766,858$ & $7,564,329$ \\
\hline 2001 & $82,186,280$ & $6,797,282$ \\
\hline 2002 & $73,124,114$ & $5,925,272$ \\
\hline 2003 & $44,114,263$ & $3,816,573$ \\
\hline
\end{tabular}

Graph 1. Evolution Of Salt In Mexico ${ }^{4}$

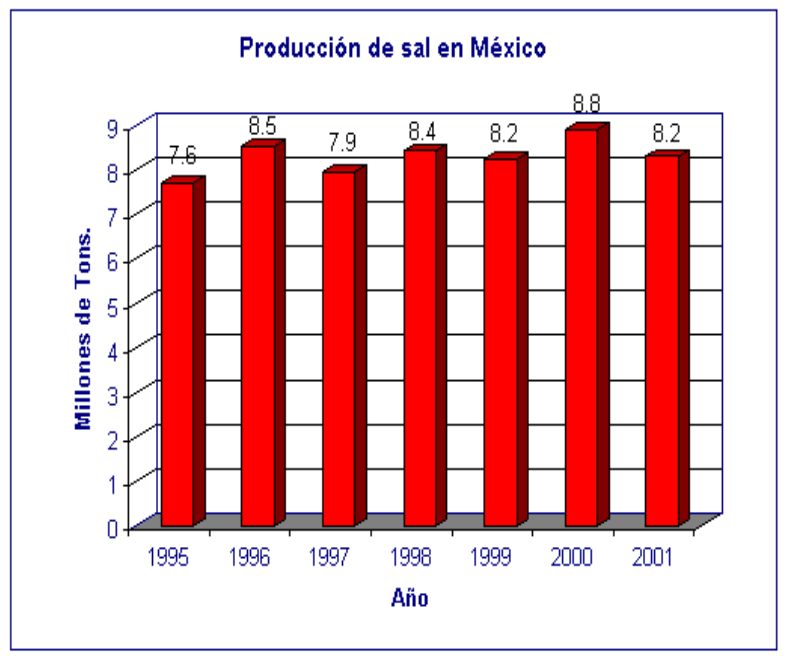

\section{TRADE BALANCE}

The trade balance for the national salt industry indicates a surplus since Mexico is self-sufficient and exports a large quantity; however, most of this external trade activity belongs to Baja California (80\%), since the other salt mines in Mexico (20\%) produce for domestic consumption.

${ }^{3}$ Cf. SE. Sistema de Información Comercial de México (SICM).

${ }^{4}$ Rf. Consejo Mexicano de Recursos Minerales y AMISAC. 
Grapht 2. Salt Trade Balance In Mexico ${ }^{5}$

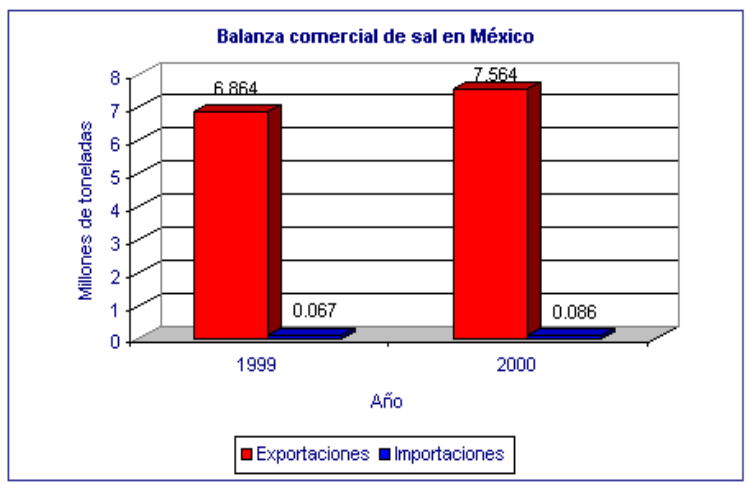

ESSA: EXPORTADORA DE SAL, S.A. DE C.V.

ESSA was established in 1954 by the North American ship owner Daniel K. Ludwig to exploit national mine reserves.

In those days, there was a Comisión de Fomento Minero which once had in its possession, as national patrimony, the territory where Guerrero Negro is now located. At that time, ESSA tried to take advantage of the salt in this territory and export it to the market on the west coast of the USA and Canada.

In the 60s, Japan began to formally import salt from Mexico for the production of caustic soda, chlorine and sodium carbonate. Japan also needed it as an intermediate raw material for its reborn postwar industries. Due to a constant increase in Japan's imports, Lugwig found it necessary to build a worthy shipping company in Isla de Cedros, Baja California Sur, where salt was sent to Japan on large boats navigated by their own seagoing companies.

In April, 1973, Mitsubishi Corporation, one of the most important Japanese trading companies and one which had already failed at its attempts to develop a salt mine in Australia, bought $100 \%$ of ESSA's shares from Daniel Ludwig. However, the Comisión de Fomento Minero supported a plan for the "mexicanization" of the mining that the then existing law had established, which led to Mexico's acquiring 25 per cent of the shares in October of that year, making it a commercial shareholder of Mitsubishi Corporation for a brief period of time.

Later on, "in 1976, the Comisión de Fomento Minero obtained the remaining 26\% of the shares from Mitsubishi Corporation, making ESSA a majority state shareholder company."

Currently, $51 \%$ of the shares ESSA possesses are in the hands of the Mexican government, the other $49 \%$ are in the hands of the Japanese transnational Mitsubishi Corporation.

ESSA has become one of the most important salt mining companies in the world. Seven million tons of salt are now exploited in Laguna de Ojo de Liebre and in Guerrero Negro. ${ }^{7}$

5 Rf. Banco Nacional de Comercio Exterior, S. N. C. y Consejo de Recursos Minerales.

${ }^{6}$ Cf. Motor de Búsqueda: Página oficial de ESSA. "La Empresa de Participación Estatal Mayoritaria Exportadora de Sal S.A. de C.V." (9 de febrero del 2005)

${ }^{7}$ Ídem 


\section{SALT PRODUCTION SYSTEMS}

Mining salt in Mexico is called "sal solar" which includes several different methods:

\section{Sea Salt Mining}

This method of mining covers $95 \%$ of solar salt produced in the country and consists of placing seawater in tanks prepared on beaches, allowing the sun and wind to do their work, evaporating the water until only salt crystals are left in the tanks, now that the brine (salt and water, the former in larger quantity than the latter) has reached its saturation point. This process may vary in the different salt mines that carry out fractional crystallization, crystallization with unpurified brine and in trough-like salt mines. ${ }^{8}$

\section{Production Of Vacuum Packed Refined Salt.}

Due to the complexity of this process, a plant called a refinery, was specifically designed to carry out this process. The plant is basically made up of machinery and equipment for evaporation and heat exchangers. Once this process has taken place, a much whiter and more crystalline salt is obtained, with a high degree of purity (99.5\%) and free of all foreign objects since it has undergone a very rigorous purification process.

\section{Salt In The Endorreic Basins}

There are many salt basins in Mexico that produce this kind of salt; however, due to its poor quality and the small amount produced, they have remained limited to local markets. This product is directed to certain industries that do not require high quality salt because it may be used for fodder or for tanning, just to mention a few. This process consists of cracking open the ground in the basins along longitudinal cuts so that superficial deposits can be exploited. Wells can also be dug to make the most of the brine in the subsoil. Once the brine is obtained, it is deposited in the evaporation equipment that then crystallizes the salts. ${ }^{9}$

Figure 1. Kinds Of Hydrologic Basins

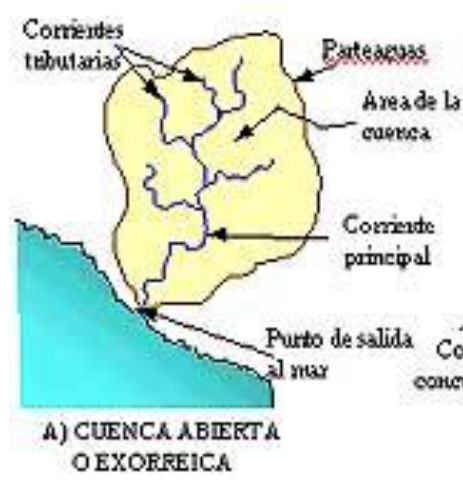

A) CUENCR ABIE
OEXORREICA

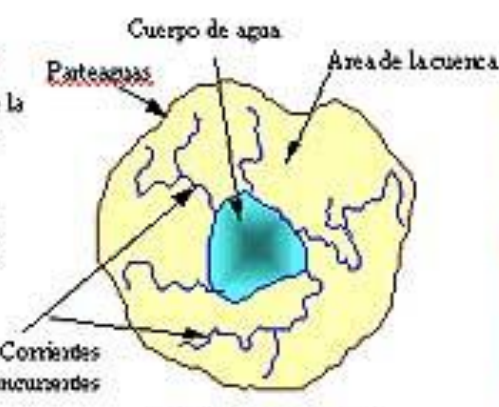

B) CUMRCA CERRADA OEMDORREICA

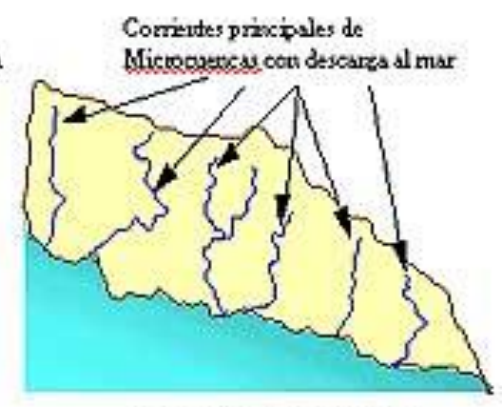

C) Cumicas costras

${ }^{8}$ Íbidem

8 Cf. Comisión Nacional del Agua. 


\section{INTERNATIONAL SALT MINING INDUSTRY}

Mexico ranks number seven worldwide in the production of salt and ranks first in Latin America. ${ }^{10}$ International organizations and enterprises related to the worldwide salt demand are as follows: ${ }^{11}$

- UNICEF.

- International Network against Disorders due to Iodine Deficiency.

- International Committee against Disorders due to Iodine Deficiency.

- International Commission on the History of Salt.

\section{SOME SALT MINING ORGANIZATIONS ARE:}

\section{Salt Mining Organizations In North America}

- Salt Institutes.

- Canadian Salt Producers.

\section{Salt Mining Organizations In Europe}

- $\quad$ European Association of Salt Producers.

- $\quad$ French Salt Mining Committee.

- $\quad$ English Association of Salt Producers.

- German Salt Mining Industry.

\section{Salt Mining Organizations In Asia}

- $\quad$ Tobacco and Salt Museum.

- $\quad$ Organization of Japanese Salt Mining

- Industries.

Table 3. Estimated Numbers For Salt Mining Industry For 1999-2000 ${ }^{12}$

\begin{tabular}{|l|c|c|}
\hline \multicolumn{2}{|c|}{ Production Of Salt Worldwide ( Tons) } \\
\hline \multicolumn{1}{|c|}{ Country } & $\mathbf{1 9 9 9}$ & $\mathbf{2 0 0 0 / \mathbf { e }}$ \\
\hline United States & $44,900,000$ & $45,300,000$ \\
\hline China & $28,100,000$ & $30,000,000$ \\
\hline Germany & $15,700,000$ & $15,800,000$ \\
\hline India & $14,500,000$ & $14,500,000$ \\
\hline Canada & $12,500,000$ & $12,500,000$ \\
\hline Australia & $10,000,000$ & $9,000,000$ \\
\hline Mexico & $8,235,620$ & $8,834,370$ \\
\hline France & $7,000,000$ & $7,100,000$ \\
\hline Brazil & $6,900,000$ & $7,000,000$ \\
\hline Great Britain & $5,800,000$ & $5,700,000$ \\
\hline
\end{tabular}

9 Cf. Asociación Mexicana de Ingenieros en Seguros. "La Industria Salinera en México". $10 \mathrm{Cf}$. Ídem

11 Cf. http://www.amisac.org.mx/page11.html “AMISAC”. (03 de marzo de 2005). 
Graph 3. International Production For 1999-2000

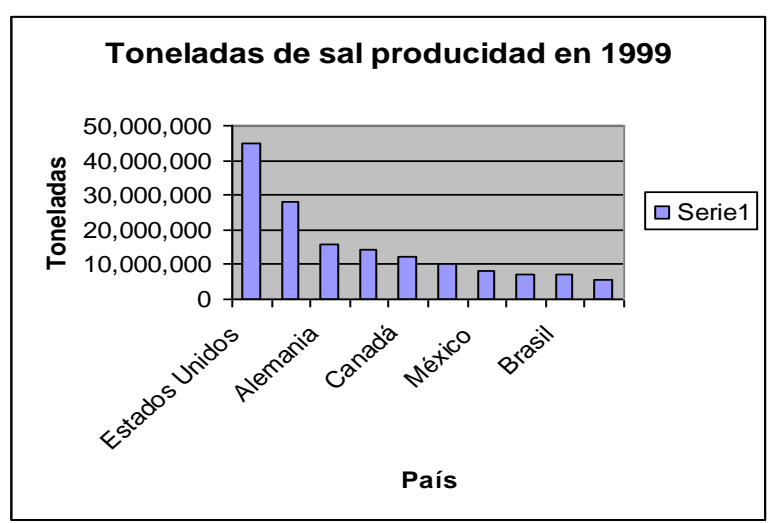

The salt mine in Guerrero Negro is, without doubt, the most important one in the Mexican Republic since it produces 5 million tons yearly; the salt mine in Japan is next in size and production, producing 3 million tons; an insufficient amount for its own consumption. There are 4 salt mines in Australia, which together produce 5 million tons. These three countries produce 13 million tons of salt for exportation yearly.

Table 4. Estimated Numbers For Salt Mining Industry For 2001 - 2002. ${ }^{13}$

\begin{tabular}{|c|c|c|}
\hline Country & 2001 & $2002^{\mathrm{e}}$ \\
\hline United States & 44,800 & 43,900 \\
\hline Australia & 9,500 & 10,000 \\
\hline Brazil & 6,000 & 7,000 \\
\hline Canada & 12,500 & 13,000 \\
\hline China & 31,000 & 35,000 \\
\hline France & 7,000 & 7,100 \\
\hline Germany & 15,700 & 15,700 \\
\hline India & 14,500 & 14,800 \\
\hline Italy & 3,600 & 3,600 \\
\hline Mexico & 8,900 & 8,700 \\
\hline Poland & 4,200 & 4,300 \\
\hline Russia & 2,800 & 3,000 \\
\hline Spain & 3,200 & 3,200 \\
\hline Ukraine & 2,300 & 2,400 \\
\hline United Kingdom & 5,800 & 5,800 \\
\hline Other Countries & 53,200 & 48,000 \\
\hline Total Worldwide ( rounded off) & 225,000 & 225,000 \\
\hline
\end{tabular}

\footnotetext{
${ }^{13}$ Note: On Table 4, the U.S.A does not include Puerto Rico. Cf: Mineral Commodity Summaries.
} 
Table 5. Percentages Of The Market Share

\begin{tabular}{|l|c|}
\hline \multicolumn{2}{|c|}{ Worldwide Market Share ${ }^{\mathbf{1 4}}$} \\
\hline Country & Percentage \\
\hline United States & $21 \%$ \\
\hline China & $15 \%$ \\
\hline Germany & $7.5 \%$ \\
\hline India & $6.5 \%$ \\
\hline Canada & $4.7 \%$ \\
\hline Australia & $4.4 \%$ \\
\hline Mexico & $4.1 \%$ \\
\hline France & $3.5 \%$ \\
\hline Brazil & $3.3 \%$ \\
\hline Great Britain & $2.8 \%$ \\
\hline Other Countries & $27.2 \%$ \\
\hline
\end{tabular}

Graph 4. Percentages Of Worldwide Market Share Of Salt ${ }^{15}$

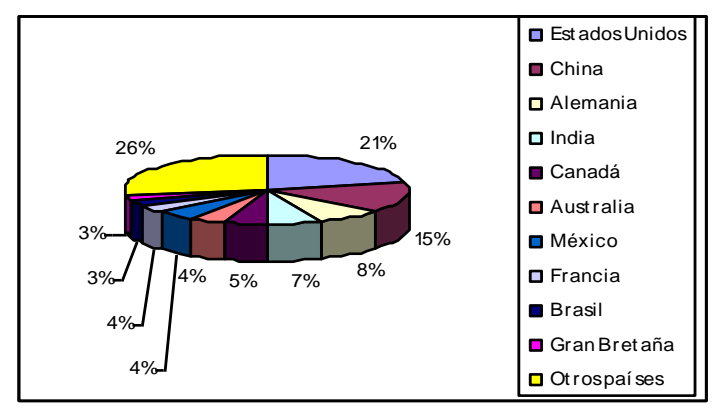

\section{SALT DEMAND}

The demand for grain salt depends on the population growth; so evident that in the last 25 years patterns of consumption have been changing; now grain salt is just as much in demand as refined salt. Both are obtained by using the best technology and always focusing on the needs of the customer. It can be said that the demand for salt is relatively satisfied as it is a staple in the human diet; therefore, its consumption is constant, although in varying proportions.

There are several different industries that depend on salt to carry out their production. For example, salt is used in the chemical industry, for making medicine, in cattle raising, in the tanning of hides and of course, for human consumption.

“The nominal price of grain salt is $\$ 1,100$ a ton, one of the cheapest products for the consumer.". ${ }^{16}$

\footnotetext{
${ }^{14}$ Cf. Ídem

${ }^{15} \mathrm{Cf}$. Ibidem

${ }^{16}$ Rf. SECRETARÍA DE ECONOMÍA. “Guías Empresariales. Inicie y Mejore su Negocio”. México.
} 


\section{USES OF SALT}

Salt has more than thirteen thousand different uses; some of its main uses are as follows:

\section{Human Consumption}

Salt plays an important role in the human diet and is also widely used for preserving food.

\section{Chemical Industry}

It makes possible the manufacture of glass, soap and detergents, plastic, paper, paints, synthetic rubber, cosmetics, medicine, electric batteries; alkaline chlorine, caustic sodium, metallic sodium, hydrochloric acid, sodium chlorate, sodium perborate, sodium bicarbonate, for water treatment and others in the petrochemical industry.

\section{Brine (Dissolution Of Salt And Water)}

It is commonly used in many freezing establishments for transporting liquids or gas used in refrigeration to cold storage rooms, all possible thanks to the low freezing temperature of the brine, which allows it to transmit the cold without crystallizing.

\section{Fur Preservation:} tanning." 17

"After weighing skins, they are preserved in salt so that they can be transported and stored until ready for

\section{Medicine}

Salt can be used for the treatment of cancer, in drugs and pharmaceuticals.

\section{Other uses}

For air conditioning systems, feed for animals, pottery, carbon desulfurization, perforating fluids, explosives, herbicides and pesticides, household products, the processing of minerals and metallurgy, grooming products, rubber, textiles and dyes, among many others.

Salt, depending on how it is used, must meet certain requirements. For example, if it is used to de-ice roads, the quality of the salt does not matter. However, some states in the USA require it contain $97.5 \%$ NaCI.

Salt used for human consumption must contain at least 99.9\% NaCI, which means it must be very pure.

Salt used for the preservation of vegetables must not contain any calcium or magnesium so that the tissue does not harden. ${ }^{18}$

\footnotetext{
${ }^{17}$ Rf. LIMÓN ARIZA, Héctor. (1991) “Síntesis de la Historia de la Industria Salinera”. Primer Foro Nacional de la Industria Salinera.

${ }^{18} \mathrm{Cf}$. http://www.segemar.gov.ar/p ofera regiones/oferta/sal/usos\%20y\%20especificaciones/usos $\% 20 \mathrm{y} \% 20$ especificaciones.htm. "Usos y Especificaciones". (9 de febrero del 2005).
} 
Graph 5. Salt Consumption - End Use ${ }^{19}$

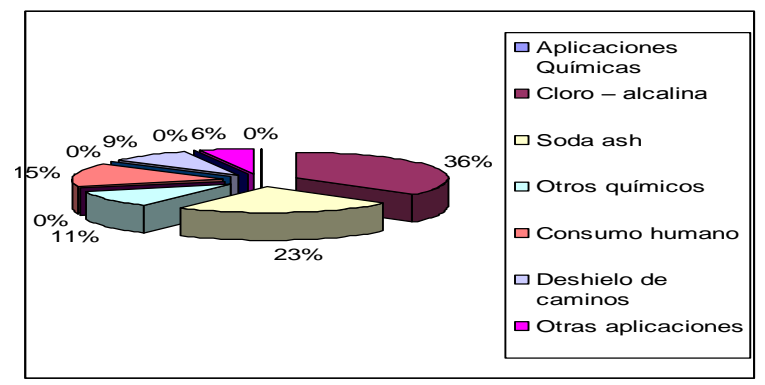

\section{SALT MINE YIELDS AND TYPES OF SALT} water. ${ }^{20}$

The average salt mine yields approximately 1.3 tons of salt for every 1,000 cubic meters of processed

The salt obtained is then classified according to the level of sodium chloride found in it: first class, that which has 96 per cent salt and is used for foods; second class, that which has 94-95 percent salt and is used in the chemical industry; and third class, that which has $90-91$ per cent salt and is used in refrigeration and other industries. ${ }^{21}$

\section{TARIFFS}

The salt trade is a very touchy subject when referring to tariff exemption. The two largest producers of salt in the Northern Hemisphere that have a free market are the USA and Canada. Countries like Mexico and Chile have a tariff between 6 to $13 \%$ and are committed to freeing it. On the other hand, some Caribbean and Central American countries maintain their tariffs above $15 \%$ and are committed to freeing this tariff in about 15 years.

As well, salt can be classified according to how it is extracted, we have:

- Rock salt: which is extracted from deposits formed many years ago?

- Manufactured salt: This is obtained from the evaporation of natural brine found underground.

- Solar salt: This is obtained from the evaporation of seawater or salty lake water, as seen before.22

\section{LEVELS OF SALINITY IN WATER}

The concentration of minerals in the seas of long ago was nine parts to each one thousand. Nowadays, the world's seas are much saltier and have a larger concentration of minerals that are about 36 parts for each one thousand. This figure varies slightly in different parts of the world. In subtropical regions, there is frequent evaporation; especially in the Sargazos and the Caribbean Sea; this causes the water to be saltier and reaches up to 37 parts for each one thousand. The Red Sea has one of the largest concentrations of salt in the world with $40-41$ parts for each one thousand. There are frequent floods in the Amazon; these stagnant waters also go into the sea, which then causes a slight decrease in its salinity; however, the ocean currents and wind balance the local differences of levels of salt.

Even though the salinity of water varies considerably all over the world, it is quite constant within each area; this means that conditions necessary for marine life are homogeneous. However, there are regions that have a large

19 Cf. Roskill.

${ }^{20}$ Rf. SECRETARÍA DE ECONOMÍA. "Guías Empresariales. Inicie y Mejore su Negocio”. México.

${ }^{22}$ Idem. 
variety of salt deposits. Such is the case of the Arctic where along the coast one can see changes in the color of the water because of these differences of salinity.

Table 6. Minerals In The $\mathrm{Sea}^{23}$

\begin{tabular}{|c|c|}
\hline Minerals In Water & Percentage \\
\hline Chloride & $19.8 \%$ \\
\hline Sodium & $11.1 \%$ \\
\hline Sulphate & $2.8 \%$ \\
\hline Magnesium & $1.3 \%$ \\
\hline Calcium & $0.4 \%$ \\
\hline Potassium & $0.4 \%$ \\
\hline
\end{tabular}

\section{PROBLEMS WITH THE SALT MINING INDUSTRY IN MEXICO}

When it became known that a project was underway for the construction of a salt mining plant in San Ignacio, located just 143 kilometers from Guerrero Negro, some problems arose over the viability of its construction. The problem stemmed from two different plans. On one hand, there was a need to improve levels of efficiency of operation by the company Exportadora de Sal S.A. (ESSA), because of the projected volume, and on the other hand, the ecological impact this new salt mining plant could have on Laguna de San Ignacio. This region is part of the Reserva de la Biósfera del Vizcaíno, which is included in the area declared a refuge for the gray whale by the Mexican government and patrimony of humanity by UNESCO. Because of these arguments, the President of the Republic officially announced the complete cancellation of this project "Salitrales de San Ignacio".24

\section{OTHER INTERESTING FACTS}

- Without salt in the organism, the heart would not beat and the muscles could not contract.

- Scientists suppose that life originated in the sea; if this is so and life came from salt water, this would explain why all organisms use salt.

- $\quad$ Salt is also known by the terms halite or sodium chloride.

- $\quad$ Salt is used for healing since it coagulates the elements that meat is made up of (proteins), contracting the tissue.

\section{THE ECOSYSTEM OF LAGUNA DE SAN IGNACIO ${ }^{25}$}

Laguna de San Ignacio is surrounded by the Vizcaino Desert and the Pacific Ocean. Without doubt, the attraction that receives the most publicity is the gray whale; it attracts thousands of tourists each year (see México Desconocido, núm. 234, agosto 1996). However, even more so than the whale, the shores of this lake maintain a complex and fascinating ecosystem; fortunately, very little changed and rarely visited by man.

\footnotetext{
Along The Desert

One can reach the Laguna de San Ignacio from the town of San Ignacio, located on the transpeninsular highway; driving 56 kilometers on some of the worst dirt roads. The winding road passes through part of the Vizcaino Desert, where one can admire woods full of giant cardones, chollas, pitahayas, and mezquites.

${ }^{23}$ Cf. AUDERSIK Gerald, AUDERSIK Teresa "La Vida En La Tierra”. México.

${ }^{24}$ Cf. CEMDA. Centro Mexicano de Derecho Ambiental. "Litigio Ambiental".

${ }^{25}$ Cf. México desconocido No. 240 / febrero 1997 Laguna de San Ignacio, paraíso de la vida silvestre. Gustavo Danemann
} 
Some ranches can also be found in the middle of the desert, built near a few scarce springs, but they barely manage to survive the harsh climatic conditions. Lastly, the vegetation yields to the desolation of the saltpeter deposits in San Ignacio, a totally arid surface, where mirages are produced by the reflection of the sun announcing the proximity of the lake. When the coast is reached, the desert is mixed with the sand dunes that frame the huge mirror of water.

\section{The Mangrove: A Key Piece Of The Ecosystem}

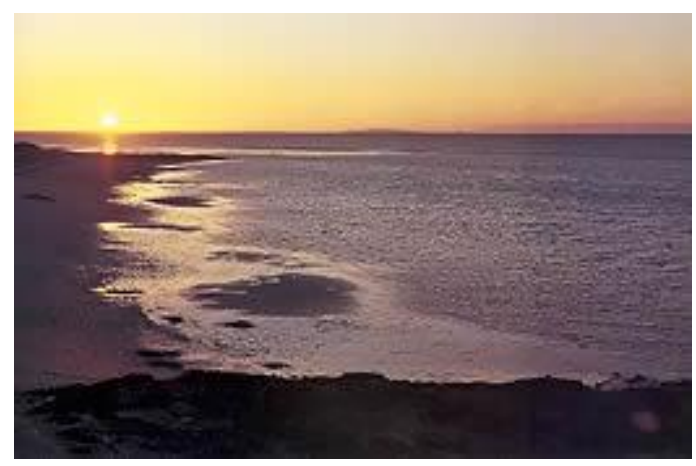

A large part of the shores of the lake, just like $90 \%$ of the coasts in Mexico, is covered with mangroves. Its roots are buried in the mud or in the sand, but are always bathed by sea water or brine water. The mangroves are a key piece in the ecosystem of the lake. Throughout a series of physiological mechanisms, these trees separate the salt from the water that their roots absorb, which is then secreted through its leaves or stems. This mechanism is comparable to a de-salting plant which provides the mangroves with salt-free water even on the seashore.

\section{The Home Of The Heron}

A long-legged and elongated figure, the heron is a permanent inhabitant of Laguna de San Ignacio. It is sensitive to any disturbance and chooses to nest in places free of predators or trespassers, so we can find colonies on islands and especially in mangroves.

\section{On The Islands}

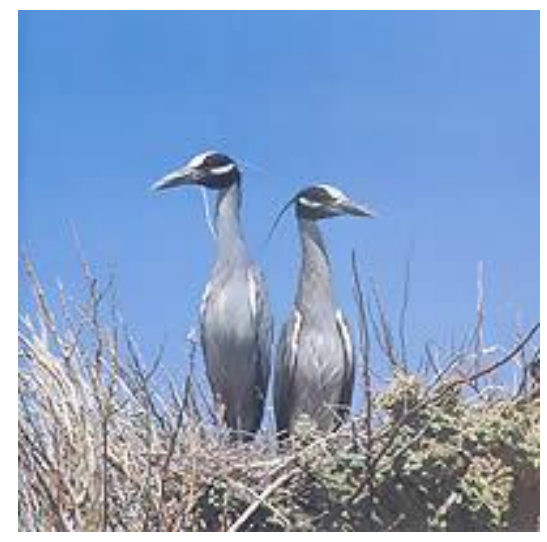


Just like the mangroves, the Pelican Islands of the Laguna de San Ignacio are inaccessible to coyotes and other land predators.

Birds take advantage of this to lay their eggs; for example, the fishing eagle, on one of the islands, keeps the reproducing colony denser than anywhere else in the world with about 150 couples.

\section{A History Of The Lake}

Laguna San Ignacio has two branches, the one that extends out towards the southeast with the greatest number of islands and mangroves; while the other on the north has whales during the summer and is the widest and deepest. It is 35 kilometers long by six kilometers wide and between 2 and 4 meters deep practically everywhere, with some channels maintained by tide currents.

\section{Laguna San Ignacio And Man}

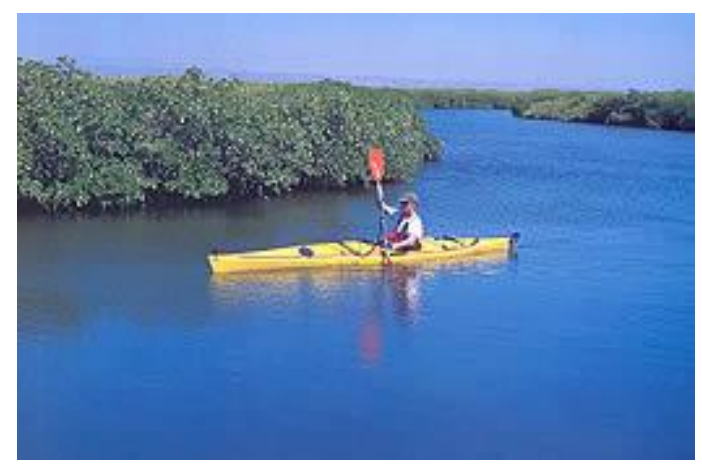

Along the shores of the lake, we can find a handful of campsites used by the local fishermen, who cope with the inclemency of the weather, a shortage of water, no services of any kind, terrible means of communication, all in order to be able to obtain a small profit from the desert or the sea.

During the summer, tourism generated around the gray whale means a bonanza for the inhabitants of the lake. This is when everybody notices these shores and the number of tourists, journalists, and celebrities add a touch of color and well-being to the place. On the other hand, when the whales leave, all that is left are the fishermen, waiting day in and day out for good weather so that they can start their fishing.

Laguna San Ignacio is truly a wildlife paradise and its natural characteristics continue to impress all those who visit. Since it forms part of the reserve of the Biósfera de "El Vizcaino", it deserves being taken care of, making sure its natural resources are used in a sustainable way. We should never forget those who are the main beneficiaries of this natural patrimony: the men, women, and children who live in Laguna San Ignacio, the true pioneers of the desert. 


\section{NOTES}

